\title{
The Origin of the Tristichaceae and Podostemaceae.
}

\author{
BY \\ J. C. WILLIS, M.A., Sc.D., \\ Director of the Botanic Gardens, Rio de Janeiro.
}

$\mathrm{S}$ is well known, and will be considered in detail in another paper, the
place to be assigned to these families in the Natural System has long been a matter of dispute. They have no nearly allied family, unless possibly Hydrostachydaceae, which live in similar conditions, and were once united to them. For the time being the dispute has ceased, since Warming placed them in the same order with the Saxifragaceae, with which they have in common a thick placenta and numerous ovules. I may remark, however, that I think they are just as near to the Nepenthaceae, which belong to another order, and probably to other families as well. It will help considerably in treating this difficult question, as well as in dealing with their evolution, if we consider in some detail their probable mode of origin.

These plants, it may be well to explain, are all water plants with a mode of life which in the flowering plants is unique to them and to the Hydrostachydaceae. With the exception of one species in the southern United States they are confined to the tropics and sub-tropics, but are very widely distributed, reaching from Java by India and Ceylon to Egypt and Madagascar, tropical and South Africa, South and Central America, and to Mexico and the United States. They live only attached to rocks, usually smooth and waterworn, or other firm substratum, in the beds of mountain streams, where the water moves rapidly over them, so rapidly that it is often full of bubbles of air. If they be placed in standing water they soon die, and they are absolutely incapable of existence on a sandy or muddy substratum.

They cling to the rocks by means of root-hairs, or more often by haptera, special adhesive organs of probable root nature, which usually appear as exogenous protuberances on root or shoot, bend downwards to the rock, and there cling by flattening out and secreting an adhesive substance.

These plants are purely vegetative during the period of high water-level due to the rains. As the water drops towards the close of the rains, they form their flowers, which open as the air touches them. The seeds quickly

[Annals of Botany, Vo1. XXIX. No. CXIV. April, 1915.] 
ripen and are shed on the rocks, where they germinate with the rise of water at the beginning of the rains. The original plants usually die, but may rejuvenesce if there be an early rise of water.

To go on now to the question of the origin of these plants in the first place, what is their origin regarded merely as Angiosperms, which they undoubtedly are? Have they, as some writers think, descended continuously in water from aquatic pre-Angiosperms, or have they sprung from the general tree of the Angiosperms, which it is generally conceded began upon land? I think that there can be no doubt that the latter supposition is correct. If they were an independent survival of pre-angiospermous water plants, one would expect to find their embryology very different from what it: actually is, for, as Warming, ${ }^{1}$ Went, ${ }^{2}$ and Magnus ${ }^{3}$ have shown, it is typically dicotyledonous. I think that on this ground alone they must be regarded as descendants of the general tree of the Dicotyledons.

If for the first time one saw any of their flowers without knowing from what sort of plant they came, one would never for a moment imagine them to be the flowers of water plants. They are typical simple mono- or a-chlamydeous dicotyledonous flowers, sometimes ento-, sometimes anemophilous, and always, unless they happen to be cleistogamic, awaiting the fall of the water-level to expand in the air on the dry rocks, and be pollinated there. They do not look in the least like the flowers that one would expect in plants with a long line of hydrophytic ancestry, leading back to antefloriferous days.

The fruit again is typically a land fruit. Only in the most highly modified species of the whole family-Farmeria metzgerioides-does it show any special suitability to the peculiar aquatic mode of life of these plants. Never, one would imagine, would a primitively aquatic family possess minute seeds in a capsule that only dehisced in dry air. Never would those seeds possess an outer layer of cells that became mucilaginous on wetting. ${ }^{4}$ Nor would the seedlings be so badly provided with holdfasts that they were constantly washed away. There is no disputing the evidence that these peculiar families are the descendants of other Dicotyledons, and of Dicotyledons that lived on land, even if their immediate ancestors were water plants.

The next question is, Where did their immediate ancestors live? Was it (I) on land or (2) in water, and in the latter case were they water plants (a) of the reaches between the rapids and waterfalls in which the Tristichaceae and Podostemaceae live; $(b)$ of moving water of the rivers of the plains or low country; or $(c)$ of ponds or marshes?

\footnotetext{
1 Warming : Familien Podostemaceae II. Kgl. Dansk. Vidensk. Selsk. Skr., 6 Række, ii, I882.

2 Went: Unt. über Podostemaceae. Verh. Koninkl. Akad. Amsterdam, xvi, I9ro.

3 Magnus: Die atypische Embryonalentw. d. Podostemaceen. Flora, cv, I913, p. 275.

4 This has often been described as an adaptation for clinging to the rock, by people who have forgotten that with another rise of water the seeds once more become loose and are washed away.
} 
In the first place, to consider the possibilities of their having been water plants at all, there are several facts which are opposed to this hypothesis. To begin with, their seeds, with one or two exceptions among the most modified species of the orders, but with none among the more primitive, are all alike-very numerous, minute, exalbuminous, with an outer coat of cells which become mucilaginous on wetting, and contained in capsules which open only in dry air. These seeds are singularly ill adapted to the mode of life which characterizes these families. They fall upon the dry naked rocks within a few days of the beginning of the dry season, which in most of the districts where these families grow lasts for several weeks. Before the end of it the enormous majority will have blown away, and once off the rocks their chance of reaching suitable spots for growth is practically nil. But a few remain, and when the water rises, the bulk of these will wash away. In the case of plants of Hydrobryum olivaceum or Lawia zeylanica, which I estimated to bear (where well grown) from 20,000 to 30,000 seeds on an average, the number of seedlings-or rejuvenescences-which may arise is rarely more than two or three, sometimes as many as ten, often enough one or even none. Were it not for rejuvenescence of the old thallus, one gathers the impression that the survival of some of the highly modified species like these would be problematical.

But even when they have actually germinated, many of the seedlings are washed away, and I do not think that it is much exaggeration to say that six weeks after germination each parent plant is usually represented by not more than one or two young ones.

But now, as these ill-adapted seeds are found throughout the families, except in a very few of the most modified species, it cannot be a stretch of probability to suppose that they are a legacy from the common ancestor, which consequently must in all reasonable probability have been a land plant.

Further, as the loss of seed is so tremendous, and all these plants set great numbers, it is evident that the original ancestors must have been plants which set seed freely and in great quantity, otherwise they could scarcely have adopted this mode of life. Now, as is well known, this is a character just the reverse of what is usually found in the plants of quieter water, and is therefore another argument in favour of the ancestor having been a land plant.

Again, assuming the ancestor to have been a water plant, it is evident that unless the seeds arrived at the rapids in large numbers, sufficient to allow of the enormous destruction that goes on, the chance of any modification appearing to suit the progeny to the new mode of life would be all but absolutely zero. And this is just what one cannot imagine happening. The only means of carriage to a distance that the seeds possess is to adhere to the feet of wading birds that have just been in the water, and are 
walking about on the rocks afterwards with wet feet. But if the ancestral plants were water plants of quieter water, the seeds would never be in the least likely to come into contact with the wet feet of wading birds, for they would be shed into the water and not upon dry land. And they are in no way whatever suited to being shed into water. Even if it could be supposed that birds or other animals could in some way get them attached to them. selves, the chances of more than an occasional one or two arriving at any given rapid would be infinitesimal, and the chances of that one successfully germinating and attaching itself would be even less.

Another fact that goes against the probability of water plants as ancestors is that the Tristichaceae and Podostemaceae could not, in their new mode of life, come into competition in any way with their ancestors, which would be living under entirely different circumstances. There does not, therefore, seem to be any reason whatever why the ancestral forms, or something fairly closely resembling them, should not still survive. Any catastrophe that so far upset the rivers as to destroy them would also probably destroy the Podostemaceae; but in actual fact there are no other water plants living in quieter water anywhere that seem to show the very slightest relationship to these families. The only family at all nearly related to them among the water plants, the Hydrostachydaceae (formerly included in Podostemaceae), is also described as living in rapid water in the mountains, or in estuaries, ${ }^{1}$ where the water is presumably also in movement to and fro. If there ever were any water plants of quiet water allied to these families, they have entirely disappeared.

Then again, when we consider that the first adaptation of any plant, be it of land or of water, to live upon the rocks in rapid water, must have been by a single large mutation, and when we consider that a water plant of still water would in any case have to get rid of its large intercellular spaces, thus undergoing a mutation as large as that which a land plant would have to undergo, it is evident that, so to speak, we gain nothing by making the ancestor a water plant.

It is thus fairly probable that these plants could not have arrived at the rapids where they commenced as seeds of other water plants living at a distance, when we consider the seeds which they actually possess, and which must represent the seeds of their ancestors. But there is still another possibility $(2 a)$ open, that they may have crept into their habitats (or arrived as seeds) from the reaches between the rapids. These reaches, however, are absolutely without any other water plants, the only things that one finds in them being land plants which have crept into the water at the edges by means of runners, \&c. They are floored with moving sand, upon

1 This is a very interesting point; I have little doubt that some of the Podostemaceae would also survive under such conditions. Cf. also the Algae, described by Goebel, mentioned in my Indian monograph, Ann. Roy. Bot. Gard. Peradeniya, vol. i, p. 420. 
which water plants would find it very difficult to retain a foothold in the rapidly moving water. Reaches such as these do not, whether in temperate or tropical countries, offer satisfactory places for growth to any water plants, and it is extremely rare to find such growing in them. In any case, such plants would not be likely to have creeping roots developing secondary shoots; rather they would probably have deeply growing roots to try to get a foothold.

Assuming, however, the improbable thing that such plants did exist, it is very remarkable that they have died out and left no trace, for even if we allow Natural Selection a large part in evolution, there can be no competition between them and the Podostemaceae on the rocks, and there is now nothing in the intermediate reaches. Their habit would probably be quite different from that of the Podostemaceae, and to adopt the mode of life that characterizes the latter they would have to undergo great changes in their morphology. Land plants, on the other hand, would require a great change in their anatomy. The question is a difficult one, but it seems to me that a change in morphology, such as would likely be required here, from deeply rooting plants to creeping-rooted plants with secondary shoots upon the roots, would be a larger change than the loss of the rigid anatomy, which we know may disappear to some extent in a shoot that happens to live in water. Taking this together with the absence of any water plants in the reaches, I think we may pretty safely say that the ancestor did not live there and send seeds with the current to stick upon the rocks, while it would find it almost impossible to creep on to the rocks on account of the rush of water and sand.

We are thus reduced to the first of our suppositions, that the immediate ancestors of these plants were land plants, a supposition which from any point of view is the most reasonable. It is necessary to suppose that these plants grew on the bank of the river at the rapids, on account of the difficulty about the seeds which we have already considered, but the rapids where these plants grow are always surrounded by vegetation.

Land plants living on the edge of the stream could very well put out feelers, so to speak, in the form of adventitious roots, on which, as happens in many families, secondary shoots might arise. These shoots might very easily from the first, as is evident from the behaviour of Littorella and other amphibious plants, be able to go through life in water, and as the water is sufficiently aerated would never need to develop any large intercellular spaces. Thus the only adaptation that they would require for a start would be to be able to hold firmly to the rock. This could be easily enough accomplished by the development of numerous root-hairs.

The important point here is that such 'experimental' shoots might form year after year in considerable numbers without in any way endangering the existence of the parent form, until at last the necessary 'adaptive' 
mutation (or mutations) appeared which enabled them to live permanently in the water. The primary shoot, developed on land, is always a last resource for survival, whereas water plants arriving from other placesor land plants either, for that matter-have to come as seeds, few and far between, and have, so to speak, nothing to fall back upon.

Having taken to the water like this, one can imagine that these secondary shoots would flourish, for they would thus at one stroke acquire a large amount of virgin territory as yet free of any plants except an occasional Moss, and at the same time would come into a medium which afforded an abundant supply of food. The seeds produced upon them would still have a fair chance of reaching the bank in reasonable numbers. On the other hand, one can imagine the primary axis to some extent handicapped by having to start the secondaries, and by the fact that their successful growth may interfere with its own, though neither of these causes is really likely to make much difference. But anyhow, it is not difficult to imagine it some day taking to the water itself, perhaps by the appearance of some mutation which might appear among the seedlings which would tend to arise upon the rocks from the seeds of the secondary shoots, or as a direct mutation, which would then become transmissible by the seeds which would be falling upon the rocks in any case. There is a difference in anatomy sometimes seen between primary and secondary shoots which may point to their having arisen at different periods in the phylogeny of the families.

It is in some such way as this, we feel sure, that these families came into existence. Water or land plants from other places than close by could never have adapted themselves to this peculiar mode of life by the aid of seeds which would only reach the rocks on rare occasions, and would then have little or no chance of retaining their position.

Be it noted that there was, so far as we can see, no absolute necessity for these ancestral plants to become Tristichaceae or Podostemaceae. They might quite well have remained amphibious. As mutation appears usually to be quite 'indefinite', giving rise to useless characters, and as the chance of a favourable mutation arriving among a chance possible assortment is almost infinitesimal, this would lead one to infer that here at least the appearance of the necessary final mutation was perhaps determined by the conditions of life, whether directly or indirectly.

In any hypothesis whatever of the origin of these plants, a very large mutation is necessary, for the change of life in beginning to live as these families do is so great that no gradual change other than one something like that which we have sketched could effect it, and even in this the last transition must be ultimately effected by a sudden mutation. The great difficulty, upon any hypothesis, is to account for the appearance of this mutation, for we know that acquired characters, such as would be the habit 
of living in water for the secondary shoots which we have pictured to ourselves, are not hereditary. It is conceivable that something like memory may come in, and after they have lived like this for very long periods, may cause the necessary mutation to appear which will render the habit a permanent and practically irreversible one. In cases like Littorella - it is worthy of note that only genera, not families, exhibit such peculiarities-the memory may be as yet imperfect, and if one could watch them long enough, one might see a separation of a land form from a water form.

Another great difficulty which crops up upon any theory of the origin of the Tristichaceae and Podostemaceae, though it is no greater with this than with any other theory, is to explain why there are no related forms which might represent the ancestors, for as the progeny would not come into competition with the ancestors, there seems no reason why these should have disappeared. It is possible that the ancestor was already a single isolated species, and even after having given rise to the early Podostemaceae continued to live mainly in the water by secondary shoots, and was defeated by the better adapted Tristichaceae or Podostemaceae. Or again, it is possible that it was killed out in some change of conditions on land which did not affect the water plants, at least not enough to destroy them also. Or again, it may be that it will yet be discovered in some out-of-the-way district of the tropics.

Be these difficulties as they may, however, there seems good reason to suppose that these peculiar orders started as land Dicotyledons, which lived by the side of some of the many rapids in a warm country, and experimented, so to speak, with secondary shoots which they sent into the water, till on some lucky day-or other longer period of time-a mutation appeared which enabled them to live their whole life in the water from the seed, and thus opened up to them the virgin territory of the rocks in the rivers and streams of the tropical and subtropical zone.

Once the necessary mutation to enable the primary axis to live from germination in the water had been performed, this mutation would survive, and we should have the first unquestionable Tristichaceae or Podostemaceae. But having got thus far, there is, as we have seen, ${ }^{1}$ no action of natural selection in the evolution of the families from this common ancestor, and the formation of about thirty genera and 200 species. The conditions of life are too uniform to allow of serious action on the part of Natural Selection, and there is not enough competition among the individuals or with other forms of life.

Now in the origin of these families there are one or two other important points that come up. In the first place it is evident that the first change, which turned the ancestral form (whatever it was) into one of these plants,

1 Willis : On the Lack of Adaptation in the Tristichaceae and Podostemaceae. Proc. Roy. Soc., B., lxxxvii, I9I 4 , p. $53^{2}$. 
must have been a fairly large one-either the plants can live as these plants do, or they cannot. But if so, we must allow that mutations may be 'large', and we must admit that Natural Selection, which works by small variations, could not effect the change, both of these being points for which I have contended in other papers. No amount of 'small' changes will transfer these plants from another mode of life to their present remarkable one. As I find that very few people in Europe realize the conditions under which these plants really grow, it may not be amiss to mention that the edge of such a waterfall as Stonebyres, where the water is actually pouring over, would be covered with them were the fall in Brazil. Or the shallower parts of the Strid, near Ilkley, Yorks., where there was light enough, would similarly be covered with them in Ceylon.

In a later paper, I propose to deal with the evolution of these families, proposing a theory which appears applicable to evolution in general.

1 There may have been a struggle for existence among the ancestors, but only a 'large' mutation would set a plant free from that, and we have no evidence to show that desirable changes may occur in response to any need for them, and evidence as for example with the seeds of these families, to show that they do not. 


\section{$2 \mathrm{BHL}$ Biodiversity Heritage Library}

Willis, J. C. 1915. "The origin of the Tristichaceae and Podostemaceae." Annals of botany 29, 299-306. https://doi.org/10.1093/oxfordjournals.aob.a089547.

View This Item Online: https://www.biodiversitylibrary.org/item/243629

DOI: https://doi.org/10.1093/oxfordjournals.aob.a089547

Permalink: https://www.biodiversitylibrary.org/partpdf/320064

\section{Holding Institution}

Smithsonian Libraries

\section{Sponsored by}

Biodiversity Heritage Library

\section{Copyright \& Reuse}

Copyright Status: Not in copyright. The BHL knows of no copyright restrictions on this item.

This document was created from content at the Biodiversity Heritage Library, the world's largest open access digital library for biodiversity literature and archives. Visit BHL at https://www.biodiversitylibrary.org. 